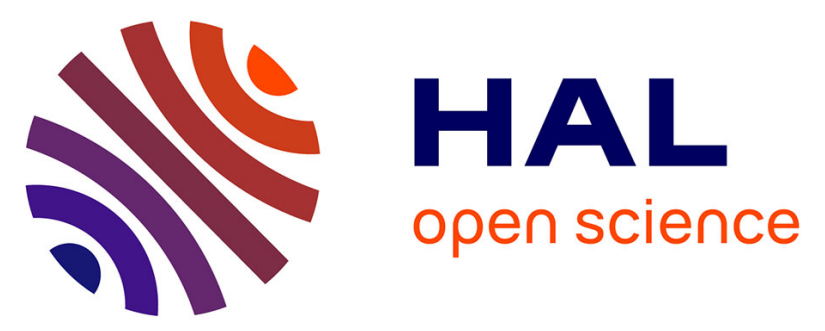

\title{
Expedition - Amazon River (Peru-Brazil) in geosciences: reporting in dry season weather (Jul / Dec 2016), using geoprocessing and transformed into Morlet wavelet
}

Newton Silva Lima, Aldemir Malveira de Oliveira, Robson Calazães, Ricardo

Figueiredo, William Quispe, José Olavo Braga, Alan S Ferreira, Eriberto

Façanha, Madalena Pietzsch, Lilian Gleicy

\section{To cite this version:}

Newton Silva Lima, Aldemir Malveira de Oliveira, Robson Calazães, Ricardo Figueiredo, William Quispe, et al.. Expedition - Amazon River (Peru-Brazil) in geosciences: reporting in dry season weather (Jul / Dec 2016), using geoprocessing and transformed into Morlet wavelet. 15th International Congress of the Brazilian Geophysical Society \& EXPOGEF, Rio de Janeiro, Brazil, 31 July-3 August 2017, Sep 2017, Rio de Janeiro, France. pp.346-352, 10.1190/sbgf2017-068 . hal-03190077

\section{HAL Id: hal-03190077 https://hal.science/hal-03190077}

Submitted on 6 Apr 2021

HAL is a multi-disciplinary open access archive for the deposit and dissemination of scientific research documents, whether they are published or not. The documents may come from teaching and research institutions in France or abroad, or from public or private research centers.
L'archive ouverte pluridisciplinaire $\mathbf{H A L}$, est destinée au dépôt et à la diffusion de documents scientifiques de niveau recherche, publiés ou non, émanant des établissements d'enseignement et de recherche français ou étrangers, des laboratoires publics ou privés. 


\section{Expedition - Amazon River (Peru-Brazil) in geosciences: reporting in dry season weather (Jul / Dec 2016), using geoprocessing and transformed into Morlet wavelet.}

Newton Silva Lima, SEDUC/ULBRA ${ }^{1}$; Aldemir Malveira de Oliveira, SEDUC/UFAM ${ }^{2}$; Robson Calazães, ULBRA $^{3}$; Ricardo Figueiredo, ULBRA ${ }^{4}$; William Quispe, Climate, ULBRA ${ }^{5}$, José Olavo Braga, ULBRA ${ }^{6}$ Alan S. Ferreira, ULBRA ${ }^{7}$, Eriberto Façanha, SEDUC/ULBRA ${ }^{8}$, Madalena Pietzsch, ULBRA ${ }^{9}$. Lilian Gleicy, ULBRA $^{10}$

Copyright 2017, SBGf - Sociedade Brasileira de Geofísica

This paper was prepared for presentation during the $15^{\text {th }}$ International Congress of the Brazilian Geophysical Society held in Rio de Janeiro, Brazil, 31 July to 3 August, 2017

Contents of this paper were reviewed by the Technical Committee of the $15^{\text {th }}$ International Congress of the Brazilian Geophysical Society and do not necessarily represent any position of the SBGf, its officers or members. Electronic reproduction or storage of any part of this paper for commercial purposes without the written consent of the Brazilian Geophysical Society is prohibited.

Abstract - This paper is a brief account of this time in the dry season the Amazon River from lquitos (Peru) and Macapá (Brazil), from July Dez 2016, within the geociences scope (Amazonia), the expedition held collecting water samples, measurements of temperature, humidity, atmospheric pressure, surface temperature of the river, wind direction and rain precipitation all georeferenced data. In preliminary results it appears that this time the temperature at the surface of the river and the environment shows up within the climate normality this time of year, it was observed climate variability the presence of the Intertropical Convergence Zone (ITCZ), with strong influences of rainfall during the delivery period, mainly in the tri-border region (Brazil-Peru-Colombia).

Index Terms: River Amazon: geociences: PeruBrazil.

\section{INTRODUCTION}

The Amazonia rich source of biodiversity forest, fresh water and oxygen, plays an important role in the global carbon by the fact that along with the oceans most carbon capture source from the atmosphere, consequently, the absorption by the trees and approximately $17 \%$ greenhouse gas emissions [1]. However, one should not forget that the role of forests in maintaining the climate of South America due to the hydrological cycle of interaction and humidity regulation within the tropical forest basin after the rains, there is an intense evaporation production and recycling of moisture returns the forest as rain again, which for researchers [2], a percentage between 30\% and $50 \%$ of the rainfall in the Amazonia are due to the evaporation recycling.

To understand the interactions between forestatmosphere, it is necessary to understand the turbulent changes in the Atmospheric Boundary Layer (ABL). This evolves continuously in response to heating or cooling surface, assuming different states that can be described accurately by phase transitions (day-night and / or vice versa) [3]. [4] shows that there are three main modes of exchanges between the surface and the atmosphere: radiation, momentum transfer and latent heat transfer and heat sensitive. Earlier research on the turbulent flows, the scope of micrometeorology in the Central Amazonia, [5] points out that the quantification of turbulent changes and their analysis should be well detailed in tropical forests, so it is necessary to perform micrometeorological measures with great representative of the regional climate. This allows to obtain good information about these turbulent flows. In [6] emphasize that [7] studies the macro circulations and mesoscale operating in the Amazonia and the dynamic processes that organize and promote the rainfall in the area. According to him, the mechanisms that trigger rain in the Amazonia can be grouped into three types:

a) Resulting daytime convection heating surface and favorable large-scale conditions;

b) Instability lines originating on the coast northnortheast of the Atlantic coast;

c) Convective clusters of meso and large scales, associated with the penetration of frontal systems in the S / SE region of Brazil and interacting with the Amazonian region 


\section{MATERIAL AND METHODS}

This work conducted during the first part of the Expedition Fluvial Peru-Brazil (Fig. 01), measured in micrometeorology order of magnitude flow analysis (Method of Covariances according [8], and graphics of rhythmic analysis of the types of times and systems responsible for atmospheric dynamics of the period according to satellite images from information [9], analyzes Transforms Wavelet of Morlet, following the methodology of [10], as the spectrum energy associated with the flow measures.

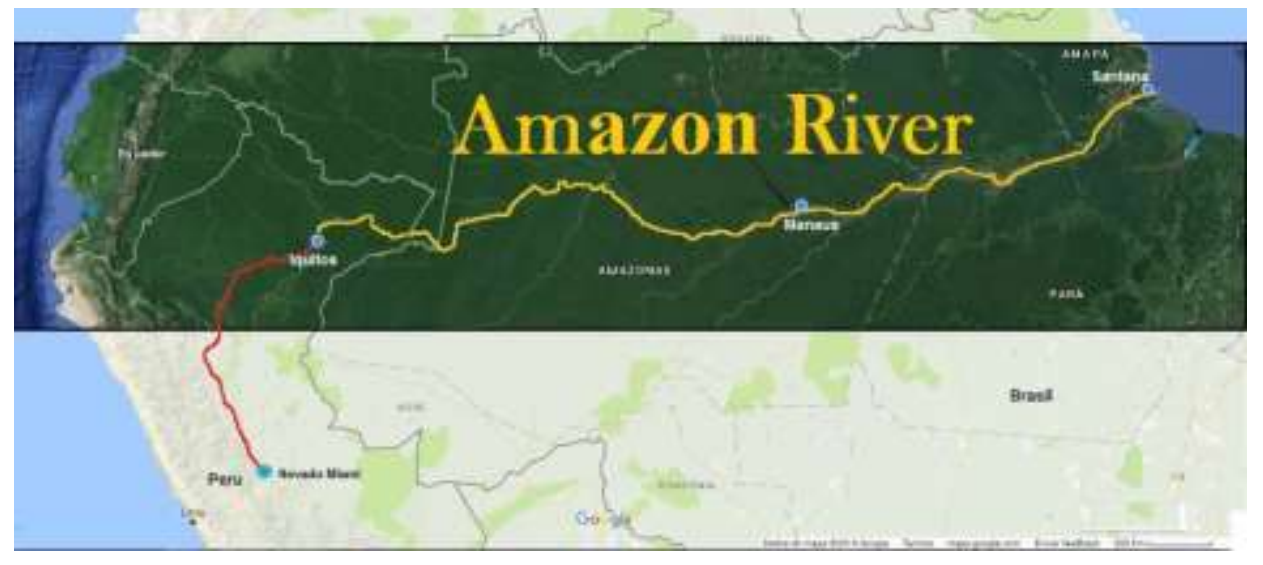

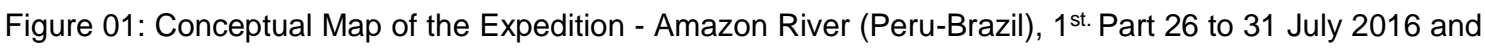
2st. Part 20 to 31 Dez. 2016 : Google Map, 2016.

\section{RESULTS AND DISCUSSION}

In Amazonia Climate [11] says that the availability of solar energy through the energy balance is 30.7 MJ.m ${ }^{-2} \cdot$ dia $^{-1}$ in June / July. These values are reduced by the air stream being on average of the order of 15 MJ.m-2.dia-1.

Figure 04 shows the satellite images panel [12] the atmospheric dynamics between days 26 July 2016 to 31 July 2016 between lquitos (Peru) and Manaus (Brazil) (yellow trace / Amazon river), in the time of 05 h 30 min (LT - Local Time, UTC -5 and -4 UTC) on all images, is observed every day strong influence of the intertropical convergence zone (ITCZ) over northern South America, with rainfall during the period, down from satellite images to see if the time series of temperature period of 120 hours uninterrupted between lquitos (Peru) and Manaus (Brazil). The average temperature was $27.45^{\circ} \mathrm{C}$ on the surface of the river, as streams of data obtained from a weather station (Davis - Vantage Vue K6250) coupled on the top deck of the boat M / Monteiro II (Fig. 2:03) 


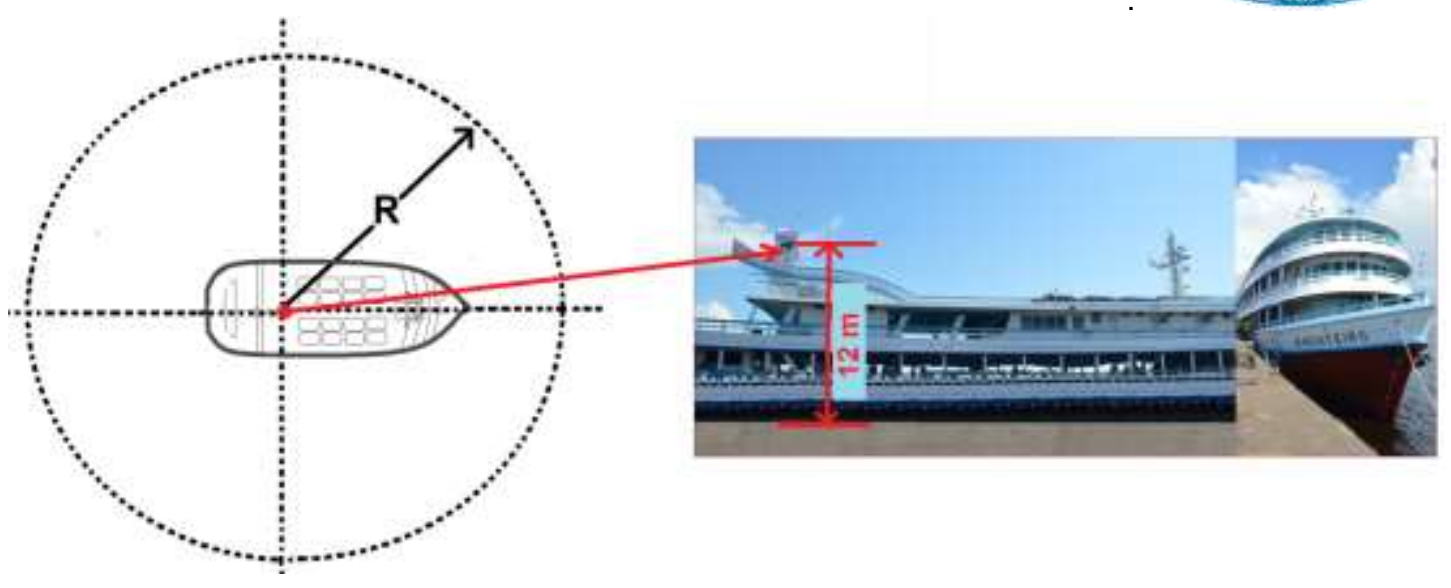

Fig. 02: Lagragian Footprint Model [13], Weather Station - DAVIS - Vantage - Vue, the boat M / Monteiro II, $300 \boldsymbol{m} \leq \boldsymbol{R} \leq \mathbf{5 0 0} \boldsymbol{m}$, between unstable and stable conditions in July 2016 .

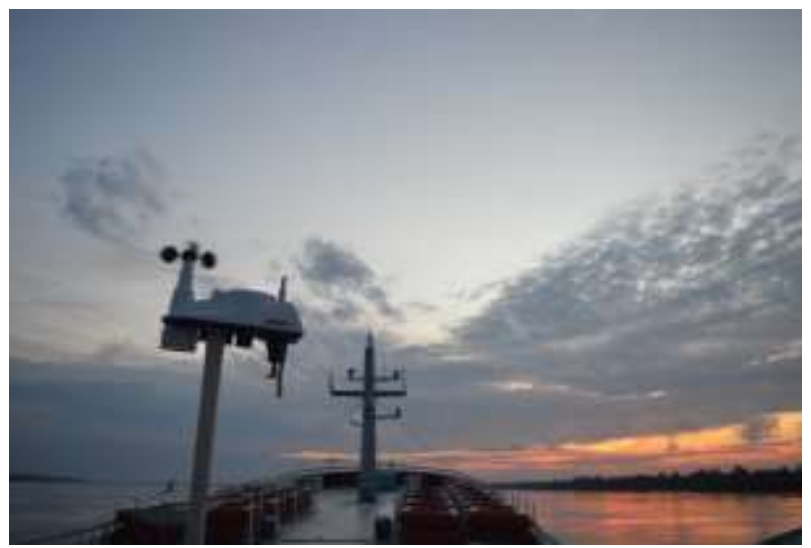

Figure 03: Weather Station - DAVIS - Vantage - Vue, on the Amazon River in July/Dez 2016. 

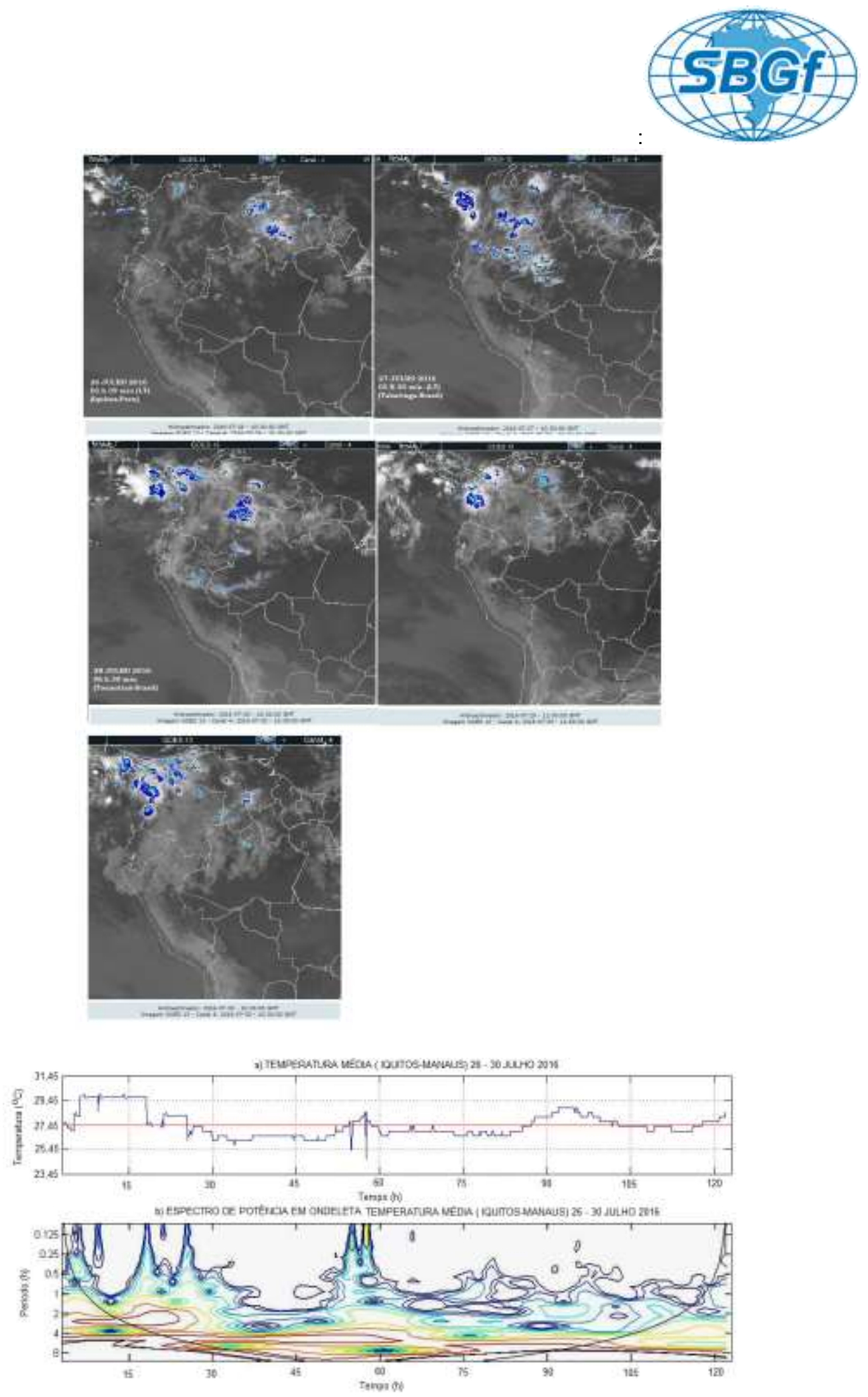

Fig. 04: Satellite images between days 26-30 July 2016, identifying the atmospheric dynamics in the north of South America at $05 \mathrm{~h} 30 \mathrm{~min}$ (LT), time series below the average temperature of the Amazon River to the observed period and Morlet wavelet transform for characterizing the length $(\mathrm{h}$ ) of occurrence of the most significant event, its duration (h) and their potential intensity warmer colors (red) at a reliability of 95\%. (Source: [12] 
Temperature series in three positions (Fig. 5) (Ambient / Vessel - $100 \mathrm{~m}$ from the edge of the channel - middle of the channel) on the 2nd. Expedition Stage (Manaus / BR - Macapá / BR), with the technical characteristics of FLIR E60. Next to the image produced by NOAA / NCEP / NWS, for Sea Surface Temperature (TSM), RTG
- High Resolution, obtained by satellite, buoys, ice cover Marine modeling, salinity, and grade 2 polynomial series mathematical modeling (Branch Analysis Method, available at $\mathrm{ftp}: / / \mathrm{ftpp}$ rd.ncep.noaa.gov/pub/data/nccf/com/gfs (prod), indicates correlation with Results obtained by the Expedition.

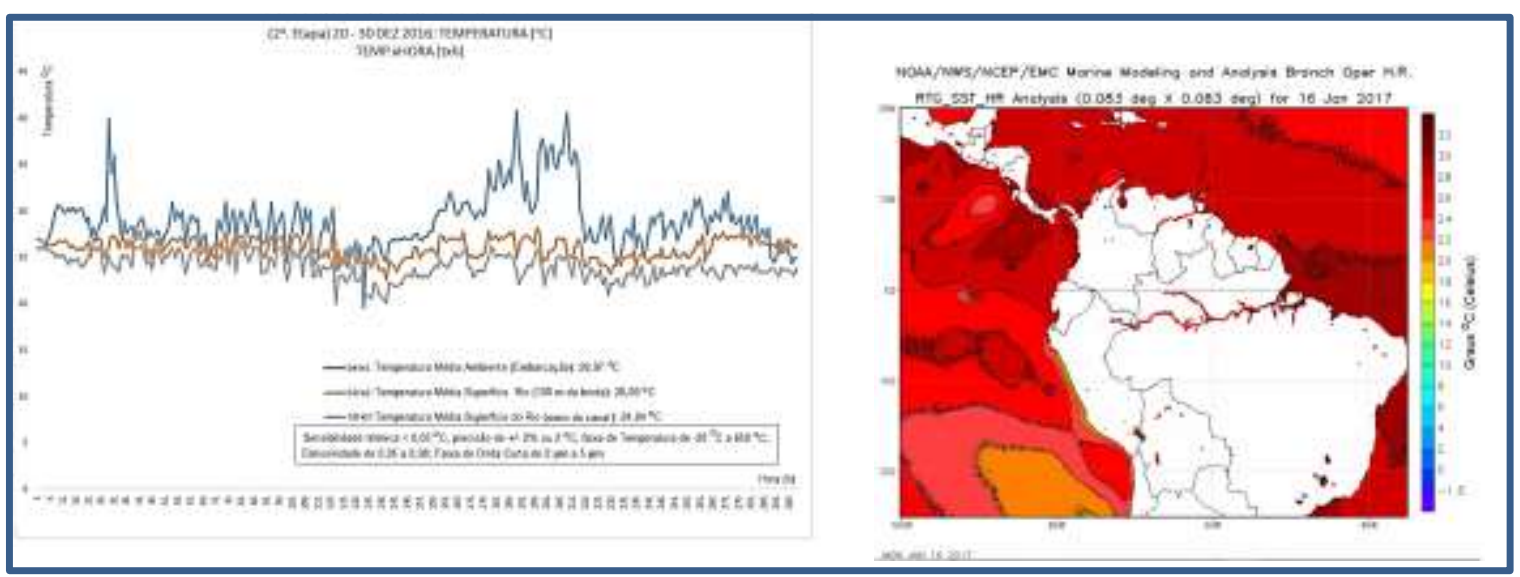

Figure 05: Data and hours with Temperature series and image produced by NOAA / NCEP / NWS, for Sea Surface Temperature (TSM), RTG - High Resolution, Jan, 2017.

\section{CONCLUSION}

This time on the Amazon River in the period 26 July - 31 Dez. 2016 was within the climate normality in the Western Amazonia. The observed period was dry river from lquitos (Peru) and Macapá (Brazil) already in Amazonia. We can not yet define the actual present time because of the Expedition is in its first stage, although preliminary results can already indicate the true Amazonian climate trend in drought. The authors hope to portray the profile of this period in greater detail, when in December reach the estuary of the river at its mouth in the Atlantic Ocean.

\section{ACKNOWLEDGMENT}

The authors are grateful to the Government of the State of Amazonas, through the Secretary of Education and Quality of Teaching (SEDUC-AM), HONDA Motor of Amazonia, the Lutheran University Center of Manaus - ULBRA (CEULMULBRA), the Governments of Peru and from Brazil, Dr. Luiz Campo Baca (President of the Research Institute of the Peruvian Amazonia and his team), the Consul of Brazil in Iquitos Dr. Salvador Roberto Vecchio, the Consul of Peru in Manaus Javier Arteta Valencia and the collaborators Abrahao Barros , Maurício Benzecry, Gilberto Carvalho, Francisco Santana. 


\section{REFERENCES}

[1] Fisch, G .; Marengo, J. A., and Nobre, C. (Amazonia Climate, 2004).http://mtcm16b.sid.inpe.br/col/cptec.inpe.br/walmeida/200 4/12.15.15.11/doc/fish.html

[2] Molion, L.C.B. Amazon rainfall and its variability. In: Hydrology and water manegement in the humid tropics "Bonell, M., Hufschmidt, M.M., Gladwell, J.S. (Eds.) International Hydrology Series, Cambridge University Press, Cambridge, UK, pp 99-111, 1993.

[3] Kaimal, J.C., Finnigan, J.J., "Atmospheric Boundary Layer Flows (Their structure and measurement)" NY, Oxford, OXFORD UNIVERSITY PRESS, 1994. 304 pp.

[4] Sellers, P. J., "Modeling Effects of Vegetation on Climate", Chapter 16, THE GEOPHYSIOLOGY OF AMAZON, R. E. Dickinson Editor, JOHN WILEY \& SONS, NY, 1985

[5] Molion, L.C.B. Dynamic Climatology of the Amazon region: precipitation mechanisms. Brazilian Journal of Meteorology, 2 (1): 107-117, 1987;

[6] Fisch, G .; Marengo, J. A., and Nobre, C. (Amazonia Climate, 2004).http://mtcm16b.sid.inpe.br/col/cptec.inpe.br/walmeida/200 4/12.15.15.11/doc/fish.html

[7] Molion, L.C.B. Amazon rainfall and its variability. In: Hydrology and water manegement in the humid tropics "Bonell, M., Hufschmidt, M.M., Gladwell, J.S. (Eds.) International Hydrology Series, Cambridge University Press, Cambridge, UK, pp 99-111, 1993.

[8] Foken, T. 2008. Micrometeorology. SpringerVerlag Berlin Heidelberg, p.320

[9] Weather of Forecast Center and Climate Studies. CPTEC / INPE, 2016. Access in July 2016: http://www.cptec.inpe.br/

[10] Torrence, C., and Compo, G. P. 1998 A Practical Guide to Wavelet Analysis. Bulletin of the American Meteorological Society, Vol. 79, No. 1, p $61-79$.

[11] Fisch, G .; Marengo, J. A., and Nobre, C. (Amazonia Climate, 2004).http://mtc- m16b.sid.inpe.br/col/cptec.inpe.br/walmeida/200 4/12.15.15.11/doc/fish.htm

[12] Weather of Forecast Center and Climate Studies. CPTEC / INPE, 2016.Access in July 2016: http://www.cptec.inpe.br/

[13] Hsieh, C.I., Katul, G.,Chi, T., 2000. An approximate analytical model for footprint estimation of scaler fluxes in thermally stratified atmospheric flows. Adv. Water Resour., 23, 765772.

\section{THE AUTHORS}

PhD Newton Silva de Lima, Climate and Environment. State Secretariat of Education and Quality of Education of Amazonas - SEDUC Amazonas and Lutheran University Center of Manaus - ULBRA - Manaus, Brazil Email: newtonulbra@gmail.com

PhD. Aldemir Malveira de Oliveira, Mathematics Department. State Secretariat of Education and Quality of Education of Amazonas - SEDUC - Amazonas and Federal University of Amazonas - UFAM Manaus, Brazil Email: amoliveira@gmail.com

Robson Calazans, (engineering student) Center Lutheran University of Manaus - ULBRA Manaus, Brazil Email: matoscalazaes@gmail.com

Ricardo Figueiredo, (engineering student). Center Lutheran University of Manaus - ULBRA Manaus, Brazil E-mail: riccardo.fig@bol.com.br

William Quispe, (engineering student). Center Lutheran University of Manaus - ULBRA Manaus, Brazil E-mail: william.exner@bol.com.br

MSc. José Olavo N. Braga. Lutheran University Center of Manaus - ULBRA - Manaus, Brazil Email: olavnbraga@yahoo.com.br.

MSc. Alan dos S. Ferreira. Lutheran University Center of Manaus - ULBRA - Manaus, Brazil Email: alansferreira@hotmail.com.

MSc. Eriberto Façanha.. Lutheran University Center of Manaus - ULBRA - Manaus, Brazil Email: efacanha@seduc.net. 
MSc. Madalena Pietzcsh. Lutheran University Center of Manaus - ULBRA - Manaus, Brazil Email: ulbramada@gmail.com.

Email: olavnbraga@yahoo.com.br.
PhD. (Chimistry) Lilian Gleicy. Lutheran University Center of Manaus - ULBRA Manaus, Brazil Email: lilian_gso@gmal.com. 